\title{
Etniske minoriteter og selvmord: rater og risikofaktorer
}

\author{
Ved Latha Nrugham
}

\section{Sammendrag}

Målet med denne unders $\varnothing$ kelsen er å oppsummere forskningsfunnene i den senere tids studier av selvmord blant etniske minoriteter. Det ble s $\varnothing$ kt etter forskningsartikler i PubMed-databasen med kombinasjoner av n $\varnothing$ kkelordene minorities, migrants og suicide. Resultatene fra de inkluderte artiklene ble inndelt i rater og risikofaktorer. Deretter ble artiklene gruppert etter geografisk område og publiseringsår. Studier av normal-

befolkningen er etterfulgt av studier av spesielle grupper. I de fleste tilfeller var selvmordsratene tilsynelatende høyere blant etniske minoriteter enn hos majoritetsbefolkningen, men det finnes variasjoner. Velkjente risikofaktorer som alkoholmisbruk og depresjon ble ikke alltid funnet i tilknytning til selvmord hos de etniske minoritetene som ble unders $\varnothing \mathrm{kt}$. Det ble identifisert noen viktige kunnskapshull. Det mest fremtredende er at de robuste forskningsdesignene man stort sett finner i studier av majoritetsbefolkninger ikke gjenfinnes i studier av minoriteter. Det er en påtagelig mangel på studier med gode kontrollgrupper, noe som kan gjøre en skeptisk til de rapporterte funnene. Jeg vil trekke noen konklusjoner ut fra dagens kunnskapsstatus, og diskutere noen av de intrikate og komplekse faktorene som innvirker på selvmordsratene hos etniske minoriteter.

\section{Innledning}

Etnisitet er sterkt knyttet til ulike indikatorer på psykisk helse, deriblant selvmordsatferd. Det kan derfor være viktig å ta hensyn til etnisitet når man skal planlegge selvmordsforebyggende tiltak (Clarke et al., 2008). Med etnisitet mener jeg i denne artikkelen felles kjennetegn som rase, nasjonalitet, språk og kultur

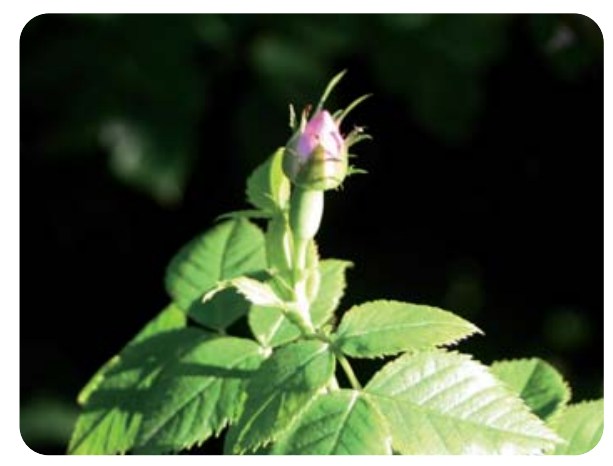

hos en gruppe individer. Selvmordsrater varierer på tvers av ulike etniske grupper (Bhui \& McKenzie, 2008). I en metaanalyse fant man sammenheng mellom selvmordsraten hos migranter i et nytt vertsland og selvmordsraten i deres fødeland (Voracek \& Loibl, 2008). Selv om selvmordsratene varierer mellom etniske grupper, er de relativt stabile innen etniske grupper. Jeg vil bruke fødeland som betegnelse på migranters opprinnelsesland, og vertsland som betegnelse på landet

migranter kommer til eller etablerer seg i.

Det finnes ingen allment akseptert definisjon av ordet minoritet, fordi ordet har sensitive politiske og rettslige implikasjoner. I denne artikkelen har jeg akseptert at ulike forfattere bruker ulike definisjoner. Hovedsakelig brukes termen etniske minoriteter om grupper som er i betydelig mindretall i forhold til majoritetsbefolkningen og som deler en felles etnisitet som er forskjellig fra majoriteten og andre minoritetsgrupperinger. En diaspora er betegnelsen på nasjonale, kulturelle eller religiøse grupper som er spredd utenfor sitt hjemland og fortsatt holder fast på en felles identitet. Av samme grunn som det ikke finnes noen allment akseptert definisjon av minoriteter, finnes det heller ingen allment akseptert definisjon av ordet migrasjon. Ordet migrant refererer generelt sett til enhver som har skiftet bopel, midlertidig eller permanent, til et sted der personen ikke er hjemmehørende på grunn av fødselen eller juridisk sett, som for eksempel ved foreldrenes nasjonalitet. Mange av studiene omtalt i denne artikkelen gjelder hovedsakelig individer som nylig eller for flere generasjoner siden har bosatt seg i en fremmed nasjon.

To faktorer kan bidra til en forh $\varnothing$ yet selvmordsrisiko hos utenlandskf $\varnothing$ dte individer (Sundaram et al., 2006).

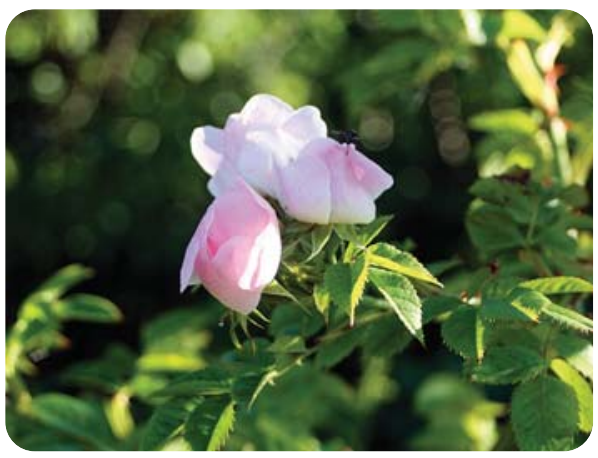

Det er: a) en relativ sosial og $\varnothing$ konomisk marginalisering av minoritetsgruppen i forhold til majoriteten i samfunnet, og b) en svekkelse av tidligere eksisterende familiebånd og sosiale nettverk. Dette resonnementet bygger på korrelasjoner mellom selvmordsrater og en mangel på sosiale bånd og integrasjon, så vel som svake sosiale relasjoner eller nettverk (Berkman et al., 2000; Qin et al., 2003).

Det er fremmet en hypotese om at psykisk helse varierer mellom ulike grupper migranter, at tilgang på psykososiale tjenester er avhengig av de juridiske rammene i vertslandet, mens bruken av slike tjenester er avhengig av migrantenes medbrakte m $\varnothing$ nster for hjelps $\varnothing$ king (Kamperman et al., 2007; Lindert et al., 2008). Men blant migranter er det noen faktorer som er ulike over tid, avhengig av vertsland og av migrantgruppe. Dette er faktorer som forventet levealder i vertslandet, hovedformålet med og varigheten av migrasjonen, migrasjonsmåte, direkte og indirekte virkninger av migrasjonen og varigheten av oppholdet i vertslandet (Kleiwer \& Ward, 1988; Burvill, 1998; Shah et al., 2009). Derfor er det lett å se at forholdet mellom selvmord og etniske minoriteter er komplekst, med intrikate forbindelser til kulturell identitet.

I en slik sammenheng er det nyttig å lage en kunnskapsoppsummering ut fra forskningen som så langt er publisert. Det er ennå ikke publisert noen slike kunnskapsoppsummeringer. I dag påvirker forskningsresultater helsepolitikk og annen politikk på regionale, nasjonale og internasjonale nivåer. Målet med denne artikkelen er derfor å oppsummere gjennom å beskrive, men ikke å sammenligne, funnene i de nyeste forskningsartiklene om selvmord blant etniske minoriteter. Artikkelen tar kun for seg funn om gjennomførte selvmord. Alle andre former for selvmordsatferd er utelatt.

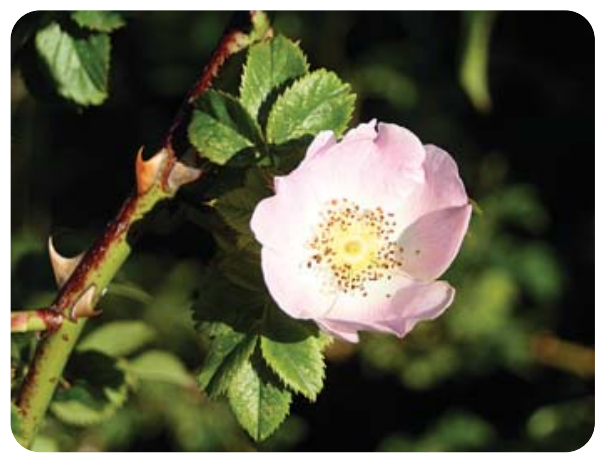




\section{Metode}

Jeg gjennoms $\varnothing$ kte PubMed-databasen etter empiriske forskningsartikler publisert på engelsk mellom 1998 og april 2010 med følgende n $\varnothing$ kkelord: migrants, minorities og suicide. Alle s $\varnothing$ keresultatene ble screenet for relevante artikler ved gjennomlesning av sammendragene. I alt 252 sammendrag ble lest. Der sammendraget viste relevans, ble hele artikkelen skaffet til veie. Referansene i disse artiklene til andre artikler ble fulgt opp, der disse var relevante. Der to artikler hadde samme budskap og datamateriale, har jeg forholdt meg til den internasjonale publiseringen framfor den nasjonale publiseringen. Én artikkel ble forkastet ut fra kvalitetsvurderinger ettersom sammendrag, tekst og tabeller ikke stemte overens. Noen artikler viste seg å være ikke-empiriske og ble derfor utelukket. I alt 26 artikler ble tatt med i det endelige utvalget.

Det er ikke gjort statistiske analyser, da dette ikke var relevant i forhold til målet med denne artikkelen. Statistiske trender som ikke viste signifikans er også utelatt. Bare statistisk signifikante funn forfatterne rapporterer om fra eget datamateriale er tatt med. I artiklene er det to ulike kategorier minoriteter det rapporteres om: 1) migrantminoriteter altså personer som har byttet bosted og blitt en minoritet i sitt nye vertsland, og 2) urfolksminoriteter - et lands urinnvånere som er blitt en minoritet i sitt hjemland. Men denne distinksjonen er ikke alltid så enkel som den kan synes. For eksempel kan ikke mennesker av afrikansk opprinnelse, som har bodd i USA i mange generasjoner, kinesere i Singapore eller mennesker av europeisk opprinnelse i S $\varnothing$ r-Afrika så lett plasseres i noen av disse to kategoriene. Vi vil derfor ikke fors $\varnothing$ ke å gruppere etniske minoriteter ut fra deres migrasjonsstatus, selv om migrasjon er viktig i prosessen med å bli en etnisk minoritet. Repatriering blir ofte vurdert som en løsning på problemene til migrantminoriteter, både av enkeltindivider og av dem som utformer politikken. Urfolksminoriteter har ikke denne muligheten.

Jeg inndeler resultatene først etter funn om selvmordsrater og risikofaktorer. Studiene blir deretter listet etter sin geografiske lokalisering i rekkef $\varnothing$ lgen: Europa, Afrika, Midt- $\varnothing$ sten og Asia, Australia og New Zealand, USA og SydAmerika. Dernest er de organisert etter publiseringsår. Studier av den generelle befolkning blir etterfulgt av studier av spesielle grupper. Til tross for denne struktureringen $\varnothing$ nsker jeg ikke å sammenlikne studier. Dette er en deskriptiv ikke en analytisk - oppsummering.

Jeg velger å gjengi detaljer fra studiene som er viktige for å forstå formålet med dem.

\section{Resultater}

Norske forskere har unders $\varnothing \mathrm{kt}$ d $\varnothing$ deligheten ved selvmord blant samer i Norge mellom 1970 og 1998. De fant en $\varnothing \mathrm{kt}$ dødelighet ved selvmord blant samer sammenlignet med befolkningen på landsbygda i arktiske str $\varnothing \mathrm{k}$ av Norge for $\phi v$ rig (Silviken et al., 2006). Selvmordsrisikoen var høyest blant samer i aldersgruppen 15-24 år: menns standard mortalitetsratio $(\mathrm{SMR})=1,8(95 \% \mathrm{CI}$ : 1,1-2,7), kvinners SMR = 3,1 (95\% CI: 1,1-6,9). Forskerne rapporterer også om $\varnothing \mathrm{kt} d \varnothing$ delighet ved selvmord blant menn bosatt i samiske kjerneområder, de sosialt sett mest fordelaktige områdene å bo for samer, SMR = 1,5 (95 \% CI: 1,1-2,2), og blant samiske menn som ikke er tilknyttet den tradisjonelle halvnomadiske reinsdyrdriften, SMR = 1,3 (95 \% CI: 1,0-1,6). I Sverige har man ikke funnet noen slik $\varnothing \mathrm{kt}$ risiko for selvmord

blant samer når man sammenlignet trendene for årene 1961-1980 og 1981-2000, men mannlige samiske reingjetere hadde $\varnothing \mathrm{kt}$ risiko for å dø i ulykker som trafikkulykker eller ved forgiftning (Hassler et al., 2004). Målt mot etnisk svenske borgere er det finner, polakker og $\varnothing$ steuropeere som har høyest selvmordsrisiko i Sverige

(Westman et al., 2006). I en dansk registerstudie blant utenlandskf $\varnothing$ dte personer med foreldre født utenfor Danmark, hadde kvinner født i Norden høyest risiko for selvmord. Kvinner født i Øst-Europa hadde en forh øyet selvmordsrisiko, mens menn født i Asia hadde lavere risiko for selvmord sammenlignet med menn f $\varnothing \mathrm{dt}$ i Danmark med danske foreldre (Sundaram et al., 2006). Blant utenlandsk fødte, der man kunne dokumentere foreldrenes fødested, var selvmordsrisikoen høyest for personer med minst én forelder født i Danmark, uavhengig av kjønn. Det var ingen forskjell i selvmordsrisiko mellom kvinner født i Asia og kvinner f $\varnothing \mathrm{dt}$ i Danmark. 


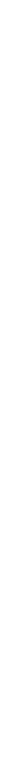

MISSOURI RIVER (WIKIMEDIA COMMONS)

I England og Wales sammenlignet man SMR for ulike grupper som hadde gjennomf $\varnothing$ rt selvmord inntil tolv måneder etter kontakt med psykisk helsevern (Bhui \& McKenzie, 2008). Forfatterne fant at gruppen av sydasiater hadde lavere SMR enn hvite. På den annen side fant de forh фyet SMR i forhold til hvite hos svarte fra Karibia, svarte afrikanske mannlige ungdommer og blant unge kvinnelige voksne fra Syd-Asia, fra Karibia og av afrikansk opprinnelse. Forfatterne rapporterer også at noen av de risikofaktorene for selvmord man vanligvis regner med å finne, var mindre vanlige blant etniske minoriteter enn blant hvite. Selvmordstanker, følelsesmessige belastninger og fiendtlighet var mindre vanlig, og vrangforestillinger og hallusinasjoner mer vanlig blant svarte afrikanere, svarte fra Karibia og sydasiater. Håpløshet og depresjon var mer vanlig blant sydasiater, og selvskading var mer vanlig blant svarte afrikanere. Eldre menn fra de fleste migrantgrupper hadde høyere selvmordsrater enn menn født i England og Wales (Shah et al., 2009).

I Storbritannia, blant asylsøkere i forvaring uten å være kriminelle, har selvmordsratene $\phi \mathrm{kt}$ fra 42/100 000 i 1997 1999 til 211/100 000 i 2003-2005 (Cohen, 2008). Forfatteren viser også at aldersog kjønnsprofilen for disse selvmordene ligner den man finner blant innsatte $\mathrm{i}$ fengslene i Storbritannia. Innsatte refererer her til alle grupper fengslede, og disse har en høyere selvmordsrate enn befolkningen for $\varnothing$ vrig. Denne unders $\varnothing$ kelsen avslørte også at data om psykisk helse hos ikke-kriminelle asyls $\varnothing$ kere i forvaring er høyst mangelfulle der de i det hele tatt finnes. En av forfatterens mange anbefa- linger er at domstolene som fastslår dødsårsak (the coroner) bør registrere status som asylsøker og etnisitet. $82 \%$ av selvmordene registrert i denne studien var foranlediget av en historie med psykiske lidelser, $14 \%$ hadde en historie med stoffmisbruk.

I Tyskland fant man for årene 19902001 en forh $\varnothing$ yet SMR blant etnisk tyske middelaldrende menn som var repatriert fra Sovjetunionen, SMR = 2,6 (95 \% CI: $1,2-4,8)$ sammenlignet med tyskere født i Tyskland når man undersøkte mortalitet ut fra eksterne årsaker (Kyobutungi et al., 2006). Forfatterne fant også at denne gruppens SMR var omvendt proporsjonal med botiden i Tyskland. I en sørafrikansk storbyforstad hadde hvite menn høyere selvmordsrater enn andre grupper (Burrows \& Laflamme, 2005). Men når forfatterne i en senere unders $\varnothing$ kelse inkluderte seks av de st $\varnothing$ rste byene i S $\varnothing$ r-Afrika, fant de at selv om selvmordsratene ofte var høyest blant hvite og menn, varierte st $\varnothing$ rrelsen på ratene og fordelingen av selvmord betydelig blant ulike grupper og kjønn innenfor samme by og blant ulike byer (Burrows \& Laflamme, 2006).

I perioden 1995-2004 hadde immigranter til Bahrain betydelig høyere selvmordsrate $(12,6)$ enn borgerne av Bahrain $(0,6)$ (Al Ansari et al., 2007). Blant disse immigrantene hadde folk fra India den høyeste selvmordsraten $(17,7)$. Forfatterne fant at menn hadde seks ganger høyere sannsynlighet for å gjøre selvmord enn kvinner. Flertallet av dem som tok sitt eget liv var under 35 år. Den vanligste årsaken til selvmord som ble registrert, var "familieproblemer av фkonomisk art”. Forfatterne antyder at den høye selvmords- raten blant indiske immigranter kan ha sammenheng med at så mange av dem kommer fra den indiske delstaten Kerala, som har dobbelt så høy selvmordsrate som resten av India. Når alle selvmord i Singapore i perioden 2001-2002 ble unders $\varnothing \mathrm{kt}$, ble følgende populasjonsjusterte rater funnet: kinesere 1 , malayer 0,5 og $>1$ for både indere og andre etniske grupper (Loh et al., 2007). Unge voksne og eldre hadde en forh øyet risiko, selv om ratene for eldres selvmord har sunket siden 1990-tallet. Selvmordsratene korrelerte også med ratene for arbeidsløshet. I Australia fant man lavere selvmordsrater blant menn født i Syd-Europa, MidtØsten og Asia og høyere selvmordsrater blant menn født i Nord-Europa og $\varnothing_{\text {st- }}$ Europa sammenlignet med dem født i Australia (Taylor et al., 1998). I den samme unders $\varnothing$ kelsen fant forfatterne at sosio $\varnothing$ konomiske faktorer spilte en viktig rolle for selvmordsraten hos menn født i Australia, hos mannlige migranter fra engelsktalende land og fra Asia, og hos ungdom, men ikke for kvinners selvmord eller for selvmord i de fleste migrantgruppene som ikke var engelsktalende. Blant kvinnelige migranter fra Storbritannia og Irland, Nord-Europa, Øst-Europa og Sovjetunionen og fra New Zealand, var det en forhøyet risiko for selvmord i forhold til australskf $\varnothing$ dte kvinner (Morrell et al., 1999). Den samme studien rapporterer også om lavere risiko for selvmord blant kvinner født i Midt- $\varnothing$ sten. Når tallene for alle migrantgrupper ble slått sammen, hadde mannlige migranter lavere selvmordsrisiko enn australskfødte, og kvinnelige migranter høyere selvmordsrisiko enn australskfødte. 
Minoritetsgrupper, spesielt menn, hadde lavere selvmordsrisiko enn hvite grupper i en kohort av australske fengselsinnsatte (Kariminia et al., 2007).

I New Zealand skjedde flertallet (75 \%) av selvmord blant maoribefolkningen blant dem som var yngre enn 35 år (Beautrais \& Fergusson, 2006). Selvmordsratene blant personer under 25 år var høyere blant maoribefolkningen enn blant resten av befolkningen. I kontrast til dette fant forfatterne at selvmord var nærmest ukjent blant eldre maori (over 60 år).

Selvmordsraten blant amerikanske indianere og Alaskas urfolk var høyere $(19,3)$ enn i den generelle befolkningen i USA $(11,2)$ i 1998-99 (LeMaster et al., 2004). Forfatterne fant at selvmord var den nest vanligste d $\varnothing$ dsårsak for aldersgruppen 15-24 og tredje vanligste dødsårsak for aldersgruppene 5-14 og 25-44, som i mange industriland. Selvmordsrater for etniske immigrantgrupper i USA ble funnet å korrelere med hvor stygge betegnelser ulike grupper er assosiert med (selvmordsrate som funksjon av hatefull omtale), etter at man hadde justert for selvmordsratene i fødelandet og gruppens st $\varnothing$ rrelse (Mullen \& Smyth, 2004). Afroamerikanere i den generelle befolkning hadde lavere selvmordsrate enn hvite, men de som gjorde selvmord var yngre enn blant hvite (Garlow et al., 2005). Dette indikerer at selvmordsrisikoen for ulike grupper er definert av ulike aldersspesifikke psykopatologiske prosesser og beskyttende faktorer, konkluderte forfatterne. I en unders $\varnothing$ kelse av selvmord hos barn og unge i Virginia i USA for årene 1987-2003, fant man at afroamerikanere stort sett hadde lavere rater enn hvite (Vieweg et al., 2005). På den annen side var forholdet motsatt i 2003 (afroamerikanere 3,0, hvite 2,1), fordi raten var $\varnothing$ kende blant afroamerikanere og minkende blant hvite. Økende inntekter ble funnet å $\varnothing$ ke den umiddelbare faren for selvmord blant tenåringer av alle raser, men spesielt blant afroamerikanere, men minket risikoen blant eldre (Purselle et al., 2009).

En studie av ofre for selvmord i 13 stater i USA (Karch et al., 2006) viste at svarte som ikke var av latinamerikansk opprinnelse hadde mindre alkohol i blodet enn andre. Hvite som ikke var av latinamerikansk opprinnelse hadde mindre kokain og mer antidepressiva og opiater i blodet. Det var ingen forskjell mellom ulike raser og etnisiteter på nivåene av amfetamin og marihuana. Forfatterne fant også at latinamerikanere i mindre grad enn andre hadde fătt diagnostisert psykiske lidelser eller mottatt behandling, selv om familiene rapporterte at avd $\varnothing$ de var deprimert like ofte som for andre grupper. De ulike gruppene hadde også ulike diagnostiske profiler. I en unders $\varnothing$ kelse av obduksjonsrapporter etter alle ungdomsselvmord mellom 1989 og 2003 i et fylke i USA, fant man at $82 \%$ av afroamerikanerne verken hadde kokain eller alkohol i blodet, mens $41,7 \%$ av de hvite testet positivt for ett av eller begge disse stoffene (Garlow et al., 2007). På den annen side fant forskerne det motsatte mønsteret blant voksne: $27 \%$ av afroamerikanerne testet positivt, mot 7,7 \% av de hvite.

Blant amerikanske krigsveteraner som ble behandlet for depresjon, hadde hvite pasienter en høyere selvmordsrate enn latinamerikanske og afroamerikanske pasienter (Zivin et al., 2007). I en studie av selvmord og komorbiditet i ulike etniske grupper i USA, brukte man døde av ikke-intenderte d $\varnothing \mathrm{d} s f a l l$ som referansegruppe, og fant en lav prevalens av dokumentert komorbid psykopatologi i selvmord blant svarte og latinamerikanere sammenlignet med hvite (Rockett et al., 2009). På grunnlag av resultatene av deres kryssvalideringsanalyse slutter forfatterne at det er systematiske rasemessige/etniske ulikheter i registreringssystemet. De anbefaler derfor bedre opplæring for utstedere av d $\varnothing$ dsattester, samt bedre rutiner og mer standardisering av psykologiske autopsier ved alle selvmord og andre voldsomme d $\varnothing$ dsfall med usikker årsak.

I en epidemiologisk studie fra Brasil fant man langt høyere selvmordsrater blant urfolksminoriteter i Mato Grosso do Sul-regionen (94,9 i år 2000) enn den nasjonale raten viste (4,8 samme år) (Coloma et al., 2006). I årene 2000-2003 utgjorde selvmord blant ungdom og unge voksne henholdsvis 68,9\%, 80,5\%, $92,7 \%$ og 92,3\% av dødsfallene med ekstern årsak. Forfatterne konkluderte med at selvmord står for en uforholds- messig stor andel av dødsfallene blant ungdom og unge voksne i en periode med raske sosiale forandringer mot en bedre livskvalitet.

\section{Diskusjon}

F $\varnothing$ r jeg presenterer hovedfunnene i denne oppsummeringen, vil jeg gjerne påpeke noen begrensninger ved denne studien. Dette er en forskningsoppsummering gjort av én forfatter ved bruk av systematiske metoder. Om man skal lage en systematisk forskningsoversikt kreves det derimot, blant annet, at to forskere har lest alle artiklene som presenteres i resultatdelen. En annen begrensning er at biologiske studier ble utelatt. Man kan også argumentere for at det er en begrensning at denne studien kun tar for seg selvmord, og ikke selvmordsatferd for $\varnothing$ vrig, selv om studier av slik atferd er av umiddelbar klinisk relevans. Dette vil jeg fors $\varnothing$ ke å bøte på i senere artikler.

Nok en begrensning er mangelen på allment aksepterte definisjoner og utvetydige termer innen dette forskningsområdet. Dette betyr at til tross for at de samme termene er brukt i flere studier, kan de referere til ulike grupper. For eksempel er ikke ord som minoritet eller selvmord klart definert. Selv om grundige s $\varnothing \mathrm{k}$ ble gjort, må man ha i mente at s $\varnothing \mathrm{ke}$ metoden jeg anvendte kan ha unngått å fange opp noen av de relevante unders $\phi$ kelsene. Man kan argumentere for at funnene burde blitt gruppert ut fra fødeland, men i fraværet av klare definisjoner av sentrale termer som migrant, og med denne studiens fokus på etniske minoriteter og ikke migranter i seg selv, valgte jeg å bevare fokuset som var gjort i denne studien. 
Denne oppsummeringen av ulike studier av selvmord blant etniske minoriteter har to hovedfunn. For det første viser den at ratene blant migrantminoriteter og urfolksminoriteter stort sett var høyere enn i majoritetsbefolkningen. Men dette varierte også med fødeland, alder og kjønn, og det var unntak fra regelen. For det andre viser den at velkjente risikofaktorer for selvmord, som alkohol og depresjon, noen ganger ikke var til stede blant ikke-hvite minoriteter beskrevet i disse studiene.

Men det er en rekke forhold som bør unders $\varnothing$ kes nærmere f $\varnothing \mathrm{r}$ disse funnene kan aksepteres som kunnskap. Unntakene fra $\varnothing$ kende selvmordsrater blant minoriteter kan gjenspeile hvordan selvmordsratene beveger seg i vertsnasjonen og for den spesifikke gruppen som ble unders $\varnothing \mathrm{kt}$. De to faktorene som ble funnet å bidra til en forhøyet risiko for selvmord blant migrantminoriteter, kan beskrives som relativ sosio $\varnothing$ konomisk marginalisering i forhold til fødelandet og vertsnasjonen (Sundaram et al., 2006). En tilsvarende marginalisering var også relevant i forhold til urfolksminoriteter. Disse to faktorene har konsekvenser for politikken. Vestlige land har i $\varnothing$ kende grad ført en politikk med sikte på å redusere antallet individer som søker opphold. Denne avskrekkingspolitikken inkluderer redusert tilgang til helsetjenester, utdannelse og arbeid, så vel som en utbredt praksis med å forvare individer som s $\varnothing$ ker asyl og å bare tilby tidsbegrenset framfor permanent beskyttelse (Silove et al., 2000; Robjant et al., 2009). Denne politikken trenger man å tenke gjennom på nytt.

Det er også mulig at en for høy nevner fører til en undervurdering av mortalitetsraten for ulike etniske grupper (Weitoft et al., 1999). Forfatterne gir eksempel på at når personer ble regnet med på basis av å ha inntekt i svenske kroner i stedet for på basis av å være registrert i det svenske folkeregisteret, slik man vanligvis gjør, ble den signifikant lavere mortalitetsraten blant migranter født i Tyrkia, Syd-Europa, Latin-Amerika og Afrika ikke lenger signifikant. Forfatterne forklarer at fordi folk har insentiver for å forbli i folkeregisteret, unnlater de altfor ofte å rapportere at de har flyttet. Dette fører til at telleren for disse gruppene vanligvis er for høy, slik at mortalitets- raten deres sannsynligvis undervurderes.

Det andre funnet i denne studien var at kjente risikofaktorer for selvmord ikke alltid var til stede hos minoritetsgruppene som ble unders $\varnothing \mathrm{kt}$. En mulig forklaring på forskjellene i risikofaktorer, slik som lavere forekomst av alkohol og depresjon, kan ligge i hva som gjøres til kontrollgruppe. Velkjente risikofaktorer framtrer tydelig i studier der man vanligvis sammenligner undergrupper innenfor samme etniske gruppe. Det er viktig at kontrollgruppen er så lik den studerte gruppen som mulig, bortsett fra når det gjelder studiens hovedvariabel. Men studier av selvmord blant etniske minoriteter i denne oppsummeringen har brukt kontrollgrupper fra majoritetsbefolkningen, som er en annen etnisk gruppe. Det er derfor kun med de nødvendige forbehold at disse ulikhetene i risikofaktorer kan aksepteres som reelle, selv om disse forskjellene kan være av klinisk verdi. Disse funnene må først replikeres i studier der kontrollgruppene er så like gruppen man unders $\varnothing$ ker som mulig.

Bortsett fra registerstudier og dokumentbaserte studier, er psykologisk autopsi den eneste metoden som gir mulighet for å identifisere risikofaktorer for gjennomf $\varnothing \mathbf{r t}$ selvmord. Det kan være vanskelig å avdekke etablerte risikofaktorer som depresjon eller selvmordstanker blant minoritetsgrupper som av ulike grunner ikke har tillit til formelle institusjonelle enheter. Når det gjelder psykisk helse som risikofaktor, kan det være at de som blir intervjuet ikke har hatt kjennskap til indekspersonenes indre tilstander (deres tanker og følelser). Det kan bety at det kun er tilstander som ikke lar seg skjule eller synlige endringer i sosial status som dermed blir data som analyseres.

En annen forklaring på disse forskjellene kan være at risikofaktorer ble presentert på andre måter enn forskerne er opplært til å gjenkjenne, noe det er indikasjoner på hos Karch et al. (2006). Denne forklaringen st $\varnothing$ ttes av funnene $\mathrm{i}$ studien om komorbiditet og selvmord blant etniske grupper i USA, der det ble avdekket rasemessige/etniske ulikheter i dokumentasjonen, og i studien om forvarte asylsøkere i Storbritannia som også etterspurte mer sensitivitet og bedre dokumentasjon av etniske forskjeller (Rockett et al., 2009; Cohen, 2008). Her er det også relevant å merke seg den sterke anbefalingen til forskere og registeransvarlige om å unders $\varnothing$ ke muligheten for at dødsrater blant etniske minoriteter blir estimert for lavt, slik man oppdaget blant maori og stillehavsfolk på New Zealand på 1980- og 1990-tallet (Blakely et al., 2005). Om vi utvider denne anbefalingen til forskning på risikofaktorer, vil forskere være vel tjent med å være forsiktige for å unngå å telle med falske positiver eller negativer som forkludrer statistikken. Ulikheter i risikofaktorer som gjelder for eksempel bruk av alkohol, kan fastslås med større sikkerhet enn ulikheter i indre tilstander.

I de studiene som ble inkludert, dukker akkulturasjon stadig vekk opp som en forklaring på de forhøyede selvmordsratene blant etniske minoriteter. I en kvalitativ studie av hvordan inupiatfolket forholder seg til selvmord blant ungdom, blir hensynet til tap av egen kultur ansett for å være avgjørende for utvikling av effektive forebyggings- og intervensjonsstrategier (Wexler, 2006). Forfatteren oppsummerer med at lokalbefolkningen knytter selvdestruksjon til historisk undertrykkelse, tap av inupiatkulturen (og sosiale roller) og samtidige manifestasjoner av disse historiske realitetene i alkoholisme, overgrep og vanskjøtsel.

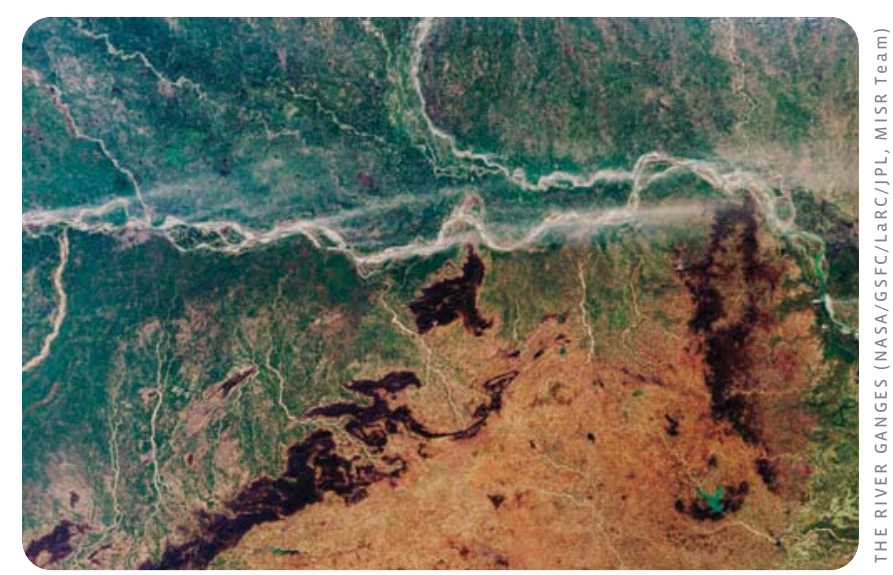




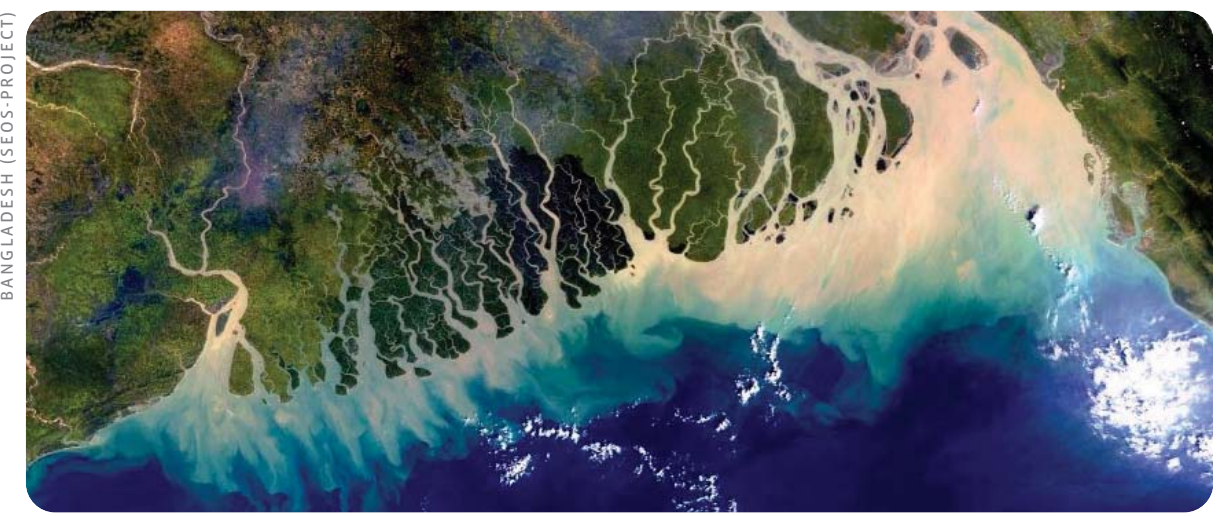

I en kvalitativ unders $\varnothing$ kelse av hva lokalbefolkningen selv anså som årsaker til og strategier for å forebygge de høye selvmordsratene hos inupiatungdommer, var fremmedgjøring et sentralt tema (Wexler $\&$ Goodwin, 2006). Forebygging ble knyttet til å $\varnothing$ ke kommunikasjonen med og forbindelsen til andre i egen kultur og spiritualitet. De voksne respondentene på undersøkelsen anså kjedsomhet som hovedgrunn til at ungdom gjorde selvmord, og mente at ungdommene måtte tilbys aktiviteter, utdannelse og $\varnothing \mathrm{kt}$ innsikt i egen kultur. I kontrast til dette mente flertallet av ungdommene at selvmord var knyttet til stress. De unge respondentene påpekte et behov for at voksne snakket med dem om hverdagslivet og framtiden slik at de fikk veiledning og st $\varnothing$ tte til å takle de vanskelighetene de møtte.

I en forskningsoppsummering fant Neff og Hoppe (1992) at det i noen teorier om akkulturasjon hevdes at de som har en stor grad av akkulturasjon opplever mest stress, mens det $\mathrm{i}$ andre teorier hevdes at de som har liten grad av akkulturasjon opplever mest stress. De påpeker at akkulturasjon er forventet å $\varnothing$ ke presset, uavhengig av om belastningene kommer av at man har adoptert den dominante kulturen eller om man har gitt opp mulige beskyttende elementer i den tradisjonelle livsstilen. I denne diskusjonen utforsket de ikke nærmere Rumbauts (1997) assimileringsparadoks, der lengden av tid en immigrant oppholder seg i vertslandet er omvendt proporsjonal med den sunne migranteffekten. Det finnes altså en $\varnothing \mathrm{kning}$ i antall spedbarn med lav f $\varnothing$ dselsvekt, risikoatferd blant tenåringer, kreft, angst og depresjon og generell dødelighet blant migranter. Den sunne migranteffekten innebærer antagelsen om at usunne mennesker har mindre sannsynlighet for å bli migranter fordi det er sperrer både i hjemlandet og vertslandet mot at de reiser og at det er derfor grunn til å tro at migranter er sunnere enn innfødte.

Denne studien har påvist mange huller i vår kunnskap. I det store og hele finner vi ikke så robuste forskningsdesign i studier av minoritetsbefolkninger som $i$ studier av majoritetsbefolkninger. Det er, som nevnt, en overveldende mangel på studier med gode kontrollgrupper. Det er få studier som fokuserer på psykososiale variabler. Sammenhengen mellom slike studier og indeksbefolkningens helsestatus (psykologisk, fysisk, sosialt) er fortsatt et uutforsket område. Bortsett fra to studier har ingen sett på kontakten med eller bruken av helsetjenester.

\section{Konklusjon}

Den viktigste lærdommen vi kan trekke av denne studien ved utforming av helsepolitikken, er at sykelighet og dødelighet blant migranter bør overvåkes og dokumenteres bedre. Vi bør s $\varnothing$ ke en bedre innsikt i integrasjonsprosesser for å forstå hvordan assimilering balanserer med akkulturasjon. For å få slik kunnskap og innsikt må vi unders $\varnothing$ ke nærmere både vellykkede og mislykkede modeller for integrasjon. En annen lærdom av denne studien er at vi trenger forskning av god kvalitet om migranters risikofaktorprofiler for selvmordsatferd. Dette er spesielt viktig i land som Norge, der migrantpopulasjonen er $\varnothing$ kende. Et siste råd er at det bør kreves av klinikere at de på en systematisk måte tar hensyn til etniske faktorer. Det er ikke bare selvmordsrater i vertslandet de bør ta hensyn til, men også risikofaktorprofilene i migrantenes fødeland.

Det kan også være nyttig å huske at blant afroamerikanere ble tilliten til statlige institusjoner og forskning erodert vekk av måten man over 40 år gjennomførte den kliniske Tuskgee-studien (Washington, 2008). I dette forskningsprosjektet unders $\varnothing$ kte de forl $\varnothing$ pet av ubehandlet syfilis ved å nekte afroamerikanske menn penicillinbehandling helt fram til 1972. Da ble prosjektet avsluttet fordi man fant det uetisk. Denne skandalen førte til endringer i de etiske reglene for forskning i USA.

Det at det i det hele tatt finnes regler for forskningsetikk, har en lignende forhistorie. Under krigsforbryterrettssakene for den berømte Nürnbergdomstolen etter annen verdenskrig var det mange tyske leger som forsvarte seg med at deres eksperimenter i konsentrasjonsleirene ikke var vesentlig forskjellige fra tidligere eksperimenter med mennesker i Amerika og Tyskland, og at det ikke var noen internasjonal rett eller andre regler som skilte mellom legale og illegale eksperimenter med mennesker (Sugarman et al., 1998). De første etiske reglene for forskning har derfor fått navnet Nürnbergkodeksen. Den skepsisen mot helsetjenester og mot forskning som disse historiske erfaringene har skapt, må overvinnes før man kan gjennomf $\varnothing$ re unders $\varnothing$ kelser med mer robuste forskningsdesign (Washington, 2008).

$\mathrm{Vi}$ må fremme minoriteters tillit til formelle og offentlige institusjoner fordi forskning ikke lar seg gjennomføre som en uformell prosess, og sjelden som et privat foretagende. Vi vet i dag mer enn tidligere, men langt fra nok om selvmordsrater og risikofaktorer for selvmord blant etniske minoriteter.

\section{Takk}

Jeg ønsker å takke Suicidologis redaktør prof. Lars Mehlum og de to fagfellene som vurderte manuset mitt. Deres bidrag har forbedret det, og har gjort at jeg ikke følte meg alene. Jeg takker også Henning Herrestad som har oversatt manuset til norsk.

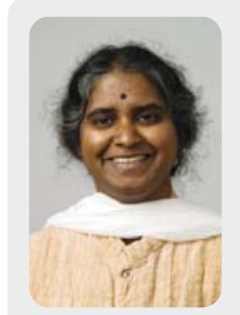

Latha Nrugham har vært ansatt som forsker ved NSSF siden 2008. Hun har publisert flere empiriske artikler og bokkapitler. Hun er i sluttfasen av sin doktorgrad fra NTNU med tema selvmordsfors $\varnothing \mathrm{k}$ blant ungdom. Nrugham har klinisk erfaring fra India og Norge og har arbeidet med gatebarn og -ungdom i Mumbai i mer enn 10 år. 


\section{Referanser}

Al Ansari, A., Hamadeh, R.R., Ali, M.K., \& El Offi, A. (2007). Suicide in Bahrain in the last decade. Crisis, 28(1), 11-15.

Berkman, L.F., Glass, T., Brissette, I., \& Seeman, T.E. (2000). From social integration to health: Durkheim in the new millennium. Soc Sci Med, 51(6), 843-857.

Beautrais, A.L., \& Fergusson, D.M. (2006). Indigenous suicide in New Zealand. Arch Suicide Res, 10(2), 159-168.

Bhui, K.S., \& McKenzie, K. (2008). Rates and risk factors by ethnic group for suicides within a year of contact with mental health services in England and Wales. Psychiatr Serv, 59(4), 414-420. Blakely, T., Tobias, M., Robson, B., Ajwani, S., Bonné, M., \& Woodward, A. (2005). Widening ethnic mortality disparities in New Zealand 1981-99. Soc Sci Med, 61(10), 2233-2251.

Burrows, S., \& Laflamme, L. Living circumstances of suicide mortality in a South African city: an ecological study of differences across race groups and sexes. (2005). Suicide Life Threat Behav, 35(5), 592-603.

Burrows, S., \& Laflamme, L. (2006). Suicide mortality in South Africa: a city-level comparison across socio-demographic groups. Soc Psychiatry Psychiatr Epidemiol, 41(2), 108-114.

Burvill, P.W. (1998). Migrant suicide rates in Australia and in country of birth. Psychol Med, 28(1), 201-208.

Clarke, D.E., Colantonio, A., Rhodes, A.E., \& Escobar, M. (2008). Ethnicity and mental health conceptualization, definition and operationalization of ethnicity from a Canadian context. Chronic Dis Can, 28(4), 128-147.

Cohen, J. (2008). Safe in our hands? A study of suicide and self-harm in asylum seekers.

J Forensic Leg Med, 15(4), 235-244.

Coloma, C., Hoffman, J.S., \& Crosby, A. (2006) Suicide among Guaraní Kaiowá and Nandeva youth in Mato Grosso do Sul, Brazil. Arch Suicide Res, 10(2), 191-207.

Garlow, S.J., Purselle, D., \& Heninger, M. (2005) Ethnic differences in patterns of suicide across the life cycle. Am J Psychiatry, 162(2), 319-323

Garlow, S.J., Purselle, D.C., Heninger, M. (2007) Cocaine and alcohol use preceding suicide in African American and white adolescents. J Psychiatr Res, 41(6), 530-536.

Hassler, S., Sjölander, P., Johansson, R., Grönberg, H., \& Damber, L. (2004). Fatal accidents and suicide among reindeer-herding Sami in Sweden. Int J Circumpolar Health, 2004, 63 Suppl 2:384-388.

Kliewer, E.V., \& Ward, R.H. (1988). Convergence of immigrant suicide rates to those in the destination country. Am J Epidemiol, 127(3), 640-653.

Kamperman, A.M., Komproe, I.H., \& de Jong, J.T. (2007). Migrant mental health: a model for indicators of mental health and health care consumption. Health Psychol, 26(1), 96-104.
Karch, D.L., Barker, L., \& Strine, T.W. (2006). Race/ethnicity, substance abuse, and mental illness among suicide victims in 13 US states: 2004 data from the National Violent Death Reporting System. Inj Prev, 12 Suppl 2:ii22-ii27.

Kariminia, A., Law, M.G., Butler, T.G., Corben, S.P., Levy, M.H., Kaldor, J.M., \& Grant, L. (2007). Factors associated with mortality in a cohort of Australian prisoners. Eur J Epidemiol, 22(7), 417-428. Kyobutungi, C., Ronellenfitsch, U., Razum, O., $\&$ Becher, H. (2006). Mortality from external causes among ethnic German immigrants from former Soviet Union countries, in Germany. Eur J Public Health, 16(4):376-382

LeMaster, P.L., Beals, J., Novins, D.K., Manson, S.M., \& AI-SUPERPFP Team. (2004). The prevalence of suicidal behaviors among Northern Plains American Indians. Suicide Life Threat Behav. 34(3), 242-254.

Lindert, J., Schouler-Ocak, M., Heinz, A., \& Priebe, S. (2008). Mental health, health care utilisation of migrants in Europe. Eur Psychiatry, 23 Suppl 1,14-20.

Loh, M., Tan, C.H., Sim, K., Lau, G., Mondry, A., Leong, J.Y., \& Tan, E.C. (2007). Epidemiology of completed suicides in Singapore for 2001 and 2002. Crisis, 28(3),148-155.

Morrell, S., Taylor, R., Slaytor, E., \& Ford, P. (1999). Urban and rural suicide differentials in migrants and the Australian-born, New South Wales, Australia 1985-1994. Soc Sci Med, 49(1), 81-91.

Mullen, B., \& Smyth, J.M. (2004). Immigrant suicide rates as a function of ethnophaulisms: hate speech predicts death. Psychosom Med, 66(3), 343-348.

Neff, J.A., \& Hoppe, S.K. (1992). Acculturation and drinking patterns among U.S. Anglos, blacks, and Mexican Americans. Alcohol Alcohol, 27(3), 293-308.

Purselle, D.C., Heninger, M., Hanzlick, R., \& Garlow, S.J. (2009). Differential association of socioeconomic status in ethnic and age-defined suicides. Psychiatry Res, 167(3), 258-265.

Qin, P., Agerbo, E., \& Mortensen, P.B. (2003). Suicide risk in relation to socioeconomic, demographic, psychiatric, and familial factors: a national register-based study of all suicides in Denmark, 1981-1997. Am J Psychiatry, 160(4), 765-772.

Robjant, K., Hassan, R., \& Katona, C. (2009).

Mental health implications of detaining asylum seekers: systematic review. Br J Psychiatry, 194(4), 306-312.

Rockett, I.R., Lian, Y., Stack, S., Ducatman, A.M., \& Wang, S. (2009). Discrepant comorbidity between minority and white suicides: a national multiple cause-of-death analysis. BMC Psychiatry, 9:10.

Rumbaut, R.G. (1997). Assimilation and its discontents: between rhetoric and reality. Int Migr Rev, 31(4), 923-960.

Shah, A., Lindesay, J., \& Dennis, M. (2009). Comparison of elderly suicide rates among migrants in England and Wales with their country of origin. Int J Geriatr Psychiatry, 24(3), 292-299.
Silviken, A., Haldorsen, T., \& Kvernmo, S. (2006). Suicide among Indigenous Sami in Arctic Norway, 1970-1998. Eur J Epidemiol, 21(9), 707-713.

Silove, D., Steel, Z., \& Watters, C. (2000). Policies of deterrence and the mental health of asylum seekers. JAMA, 284(5), 604-611.

Sugarman, J., Mastroianni, A.C., \& Kahn, J.P. (1998). Eds. Council for International Organizations of Medical Sciences (CIOMS). Interna tional ethical guidelines for biomedical research involving human subjects. Ethics of research with human subjects: selected policies and resources. University Publishing Group, 200-207.

Sundaram, V., Qin, P., \& Zøllner, L. (2006). Suicide risk among persons with foreign background in Denmark. Suicide Life Threat Behav, 36(4), 481-489.

Taylor, R., Morrell, S., Slaytor, E., \& Ford, P. (1998). Suicide in urban New South Wales, Australia 1985-1994: socio-economic and migrant interactions. Soc Sci Med, 47(11), 1677-1686.

Vieweg, W.V., Linker, J.A., Anum, E.A., Turf, E., Pandurangi, A.K., Sood, B., Fierro, M.F., \& Fernandez, A. (2005). Child and adolescent suicides in Virginia: 1987 to 2003 . J Child Adolesc Psychopharmacol, 15(4), 655-663.

Voracek, M., \& Loibl, L.M. (2008). Consistency of immigrant and country-of-birth suicide rates a meta-analysis. Acta Psychiatr Scand, 118(4), 259-271.

Washington, H.A. (2008). Medical apartheid: The Dark History of Medical Experimentation on Black Americans from Colonial Times to the Present. Doubleday Broadway Publishing Group, Random House Inc., New York.

Weitoft, G.R., Gullberg, A., Hjern, A., Rosén, M. (1999). Mortality statistics in immigrant research method for adjusting underestimation of mortality. Int J Epidemiol, 28(4), 756-763.

Westman, J., Sundquist, J., Johansson, L.M., Johansson, S.E., \& Sundquist, K. (2006). Country of birth and suicide: a follow-up study of a national cohort in Sweden. Arch Suicide Res, 10(3), 239-248.

Wexler, L., \& Goodwin, B. (2006). Youth and adult community member beliefs about Inupiat youth suicide and its prevention. Int J Circumpolar Health, 65(5), 448-458.

Wexler, L.M. (2006). Inupiat youth suicide and culture loss: Changing community conversation for prevention. Soc Sci Med, 63(11), 2938-2948.

Zivin, K., Kim, H.M., McCarthy, J.F., Austin, K.L., Hoggatt, K.J., Walters, H., \& Valenstein, M. (2007). Suicide mortality among individuals receiving treatment for depression in the Veterans Affairs health system: associations with patient and treatment setting characteristics. Am J Public Health, 97(12), 2193-2198. 